\title{
Paradoxo da Qualificação no Mundo da Competência
}

\author{
Olhai os operários do campo e da cidade \\ Eles fiam e tecem e, no entanto, andam nus
}

(Maiakovaski)

A formação teórica, validada pelo diploma, traz os conceitos, as noções, os princípios gerais que descrevem o real, o que Malglaive ${ }^{1}$ chama de "saber teórico que se mostra suficiente para assegurar o emprego".

A noção de qualificação é construída com base na sociologia e, após um grande esforço para conceituála, parece haver, há algum tempo, um consenso entre os sociólogos de que se trata de uma noção em aberto, em evolução permanente, porque tem na noção de trabalho, esta também em aberto, uma referência fundamental.

Assim, se antes se limitava ao saber e ao saber-fazer, e era, ainda, historicamente relacionada às operações de classificação dos trabalhadores e determinante dos seus salários, agora ela trata da especificidade do indivíduo, da sua originalidade, trajetória profissional, experiência, das suas capacidades e potencialidades. Seu caráter aberto de noção mostra-se, portanto, importante para a sua sobrevivência e para o estabelecimento de uma diferenciação em relação à competência.

A competência, ao contrário ${ }^{2}$, é uma demanda do patronato, e o termo é empregado por ele e não pelos sociólogos. Ela trata das exigências de cada posto, que as empresas já não sabem definir e cuja ausência se manifesta em uma pane ou no prolongamento da pane. Ela independe das especificidades do indivíduo e diz respeito às capacidades profissionais, à sua formação sistemática e socialmente controlada.

A competência se define, portanto, pelo posto de trabalho. Ela prioriza o trabalho e constitui medida de desempenho do trabalhador. Trata-se de um campo
A competência se define, portanto, pelo posto de trabalho. Ela prioriza

o trabalho e constitui medida de desempenho do trabalhador.

de conhecimento partilhado com outras disciplinas e profissões: psicólogos, antropólogos, ergonomistas, lingüistas, educadores etc. A competência encontra-se, também, e sobretudo, nos comportamentos, nas atitudes que têm por característica fundamental antecipar-se aos problemas e não apenas solucioná-los.

Para o novo modo de produção e acumulação flexível, com a organização e gestão das empresas em redes, é preciso um novo trabalhador. Não basta mais o trabalhador que desempenha funções repetitivas, mecânicas e sem iniciativa. Mesmo o trabalhador que exerce as atividades mais simples, hoje, além de fazer, deve ser capaz de pensar, dominar conhecimentos gerais relacionados ou não ao seu trabalho, interpretar textos, gráficos e tabelas, ter conhecimentos na área de informática, capacidade de interpretação de dados, iniciativa e crítica, e ser capaz ainda de trabalhar em equipe. Assim, além da educação formal, ou seja, da qualificação profissional, é necessária toda uma gama de habilidades relacionadas a novas tecnologias, bem como atitudes e comportamentos. É nessa nova lógica que surge a noção de competência.

noção de competência tem sido colocada como uma alternativa mais adequada do que a de qualificação, pois está mais sintonizada com as "novas necessidades" do 
mercado de trabalho, introduzidas pelo progresso técnico e pelas novas formas de gestão, ligadas não mais ao modo taylorista de produção, mas ao modelo baseado na organização japonesa do trabalho, batizada de toyotista. Para ganhar competitividade num mercado em crise, as empresas teriam de aumentar a qualidade e a diversidade de seus produtos e aumentar o número de lançamentos e variedades de um mesmo produto, visando nichos cada vez mais particulares do mercado.

O novo modelo de competências, do ponto de vista das empresas, com relação aos trabalhadores, combinaria, variando conforme o caso, os seguintes elementos: normas de recrutamento que privilegiam o nível de diploma; valorização da mobilidade e do acompanhamento individualizado da carreira; introdução de processos de avaliação contínua do desenvolvimento do funcionário na empresa; novos critérios de avaliação que privilegiam as qualidades pessoais e relacionais como responsabilidade, autonomia, capacidade de trabalhar em equipe, etc.; instigação à formação contínua, ou seja, aprender sempre; desvalorização dos antigos sistemas de classificação fundada nos níveis de qualificação e originados nas negociações coletivas; privilégio das negociações individuais.

Ramos $^{3}$ problematiza a qualificação enquanto relação social, colocando as competências no plano da responsabilidade do indivíduo. Afirma ela:

Tensionada teoricamente com a qualificação, a competência, como um conjunto de propriedades instáveis que devem ser submetidas à prova, opõem-se à qualificação avaliada socialmente pelo diploma, título adquirido para sempre, e pela antigüidade e à própria idéia de profissão. Opõem-se, portanto, à dimensão conceitual da qualificação. Essas competências podem ter sido adquiridas em experiências diferentes da educação formal, sendo tratadas como características do indivíduo. Não remetendo a uma categoria formalizada, a noção de competência não justificaria a reivindicação de direitos coletivos.

A competência passa a estar no princípio da organização do trabalho, no lugar da qualificação/profissão. Enquanto o domínio de uma profissão, uma vez adquirido, não pode ser questionado, as competências são apresentadas como propriedades instáveis dentro e fora do exercício do trabalho. Significa dizer que uma gestão fundada na competência encerra a idéia de que um assalariado deve se submeter a uma validação permanente, dando constantemente provas de sua adequação ao posto, de seu direito a uma promoção ou a uma mobilidade promocional.

Nessa linha de pensamento, o desempenho individual passa a ser critério de sucesso. Segundo Dupas ${ }^{4}$, o desempenho individual passa a ser o supremo critério de sucesso, num contexto em que a sociedade oferece aos cidadãos cada vez menos oportunidades.

Carnoy $^{5}$ afirma que a mundialização exerceu um impacto considerável sobre a educação, principalmente através das reformas de caráter financeiro defendidas pelas instituições monetário-internacionais. Tais reformas propunham-se, antes de tudo, a reduzir os gastos com o ensino público. Nessa versão do ajuste estrutural, a expansão da educação e o ensino de melhor qualidade inscrevem-se, portanto, no âmbito de um financiamento público, restrito nessa área. No novo ambiente mundial, é essencial que os responsáveis pelas políticas educativas tenham pleno conhecimento de que o Estado está realmente impossibilitado de aumentar o orçamento da educação e de que essa "penúria" representa uma preferência ideológica em favor do investimento privado no setor de educação. Segundo o mesmo autor, as conseqüências dessa nova organização do trabalho são importantes para a educação. Se uma pessoa é levada a trocar com freqüência de emprego, quanto melhores conhecimentos gerais tiver adquirido, tanto mais facilmente conseguirá adquirir as competências exigidas para os diferentes postos que vier a ocupar. Por outro lado, os empregadores preferem sempre contratar pessoas que, além de possuírem competências particulares, aprendem rapidamente.

O ensino profissionalizante nunca criou empregos, pois quando existem postos vacantes, a preferência é dada em geral aos jovens com formação profissional que acabam recebendo uma remuneração mais elevada. A flexibilidade na organização do trabalho significa que é mais valorizado um ensino geral de melhor qualidade que ajuda o indivíduo a coletar e interpretar informações, além de lhe proporcionar condições para resolver os problemas.

No entanto, isso significa também que a formação profissional deve ser fundamentada em um ensino geral e polivalente. É forçoso constatar, igualmente, 
que os talentos de comunicação e cooperação são tanto mais recompensados quanto mais flexível for o quadro de trabalho.

A noção de competência não se instalou, no entanto, apenas na lógica empresarial. Este modelo chegou também a todos os segmentos da cultura e aos modelos de educação de diferentes estados nacionais. No Brasil, as competências estão definidas nos documentos do MEC na Lei Federal no 9394/96 - LDB, bem como nas Diretrizes Curriculares Nacionais - DCNs - de Ensino Fundamental e de Ensino Médio, publicados como guias e enviados a todos os professores do país. Na esfera da educação, a noção de competência vem conectada a Diretrizes curriculares nacionais para o ensino médio Resolução CNE/CEB, de 26 de junho de 1998 com "a defesa da democracia da cidadania, de justiça social, de combate às desigualdades e respeito às diferenças".

Para o MEC - Ministério da Educação, o problema de diminuição da qualidade está muito vinculado à falta de recursos. Constata referido Ministério que a gestão privada do sistema priorizou uma visão economicista, com "loteamento de recursos a partir de uma relação tempo/custo, substituindo o tempo de aprender, gerando um processo de mercantilização do ensino". A maneira como o setor público desempenha seu papel na expansão e aprimoramento da educação repercute, de forma bastante diferenciada, na manutenção das tarefas educativas.

Depreende-se que, no contexto atual, as qualificações são modalidades de formação profissional e que competência é mais abrangente porque articula conhecimentos, habilidades e valores.

\section{REFERÊNCIA}

1. Malglaive, Gerard. Ensinar Adultos. Portugal: Porto Editora, 1995.

2. Costa, M.P. Certezas e Incertezas da Educação Profissional por Competências - Goiânia/GO, 2007.

3. Ramos, M. N. A pedagogia das competências: autonomia ou adaptação? São Paulo: Cortez, 2002.

4. Dupas, G. Tensões contemporâneas entre o público e o privado. São Paulo: Paz e Terra, 2003.

5. Carnoy, M. Mundialização e reforma na educação: o que os planejadores devem saber. Brasília: Edições Unesco Brasil, 2002.

6. Brasil, Lei no 9.394, de 20 de dezembro de 1996. Estabelece as Diretrizes e Bases de Educação Nacional. Brasília. DOU de 23/12/96, seção I, p.1-27, 1996.

\title{
Manoel Pereira Costa
}

\author{
Gerente de Educação Profissional do SENAI Goiás.
}

